\title{
Citizenship without representation? Blackface, misogyny and parody in Die Antwoord, Lupé Fiasco and Angel Haze
}

\section{Adam Haupt}

To cite this article: Adam Haupt (2013) Citizenship without representation? Blackface, misogyny and parody in Die Antwoord, Lupé Fiasco and Angel Haze, Communicatio, 39:4, 466-482, DOI: 10.1080/02500167.2013.852599

To link to this article: http://dx.doi.org/10.1080/02500167.2013.852599

曲 Published online: 17 Dec 2013.

Submit your article to this journal $[\pi$

Џll Article views: 235

Q View related articles $₫$ 


\title{
Citizenship without representation? Blackface, misogyny and parody in Die Antwoord, Lupé Fiasco and Angel Haze
}

\author{
Adam Haupt*
}

\begin{abstract}
This article explores Die Antwoord's blackface politics to question whether the concept of citizenship has any value in a context where marginal artists' attempts to represent themselves on their own terms are overshadowed by the global reach of corporate entertainment media monopolies, and by the legacy of racism and sexism in the music industry. It analyses the work of Die Antwoord, Lupé Fiasco and Angel Haze to contend that global capital undermines the nation-state's ability to secure its citizens' economic or cultural interests. Using Michael Hardt and Antonio Negri's concept of Empire, the author argues that corporate globalisation undermines the sovereignty of the nation-state, effectively compromising democratic ideals. The global appeal of Die Antwoord tells us a great deal about the extent to which diverse cultural expressions are marginalised, as well as the extent to which colonial conceptions of race, gender and class endear in public discourse - specifically in light of the continuing appeal of blackface in the mainstream entertainment industry.
\end{abstract}

Keywords: Angel Haze, blackface, Die Antwoord, Lupé Fiasco, minstrelsy, misogyny, parody

\section{INTRODUCTION}

This article questions whether the concept of citizenship has any value in a context in which marginal artists' unequal ability to represent themselves on their own terms is overshadowed by the global reach of corporate entertainment media monopolies and by the legacy of racism and sexism in the music industry. It analyses the work of Die Antwoord, Lupé Fiasco and Angel Haze, in order to argue that global capital undermines the nation-state's ability to secure its citizens' economic or cultural interests. The author takes his cue from Michael Hardt and Antonio Negri's (2000) argument that corporate globalisation undermines the sovereignty of the nation-state when it comes to safeguarding the interests of its citizens, effectively compromising democratic ideals (Haupt 2008). Here, the contention is that Die Antwoord's music video, 'Fatty Boom Boom', literally embraces blackface minstrelsy, possibly in an attempt to subvert criticism of their earlier work. ${ }^{1}$ Next, the author analyses Lupé Fiasco's 'Bitch Bad' in order to suggest that the legacy of blackface minstrelsy continues to influence contemporary popular culture, particularly in mainstream commercial hip-hop. Fiasco's work reveals that this legacy has not gone unchallenged. Likewise, some shortcomings in Fiasco's song have not gone unnoticed; Angel Haze's parody of 'Bitch Bad' exposes contradictions in Fiasco's treatment of gender politics. Haze allows us to consider how parody in certain forms of hip-hop have potential for critical dialogue in a context where commercial imperatives appear to hold sway over the creative and political work of artists. ${ }^{2}$ Elsewhere, the argument is made that Die Antwoord's debut music video, 'Enter the Ninja', offers an example of blackface minstrelsy in popular culture (Haupt 2012). The contention is that their 
performance of 'Doosdronk' at a music festival in the rural Western Cape appears to mock the legacy of the dop stelsel (tot system) and gender-based violence on farms (Haupt 2012). Blackface minstrelsy refers to 'white' performers literally blackening their faces to perform racist black caricatures. Writing about the history of blackface in the United States (US), Alexander Saxton $(1996,68)$ contends: 'For half a century minstrel shows provided a nationwide medium of mass entertainment, and at the end, far from fading away, they merged into vaudeville and the beginnings of cinema. Blackface minstrelsy epitomized and concentrated the thrust of white racism.' This tradition therefore permeated US popular culture, including early cinema. Die Antwoord's use of 'white' Afrikaans working-class and 'coloured' working-class stereotypes and cultural expressions amounts to blackface despite arguments that they embrace parodic and ironic strategies. In his analysis of 'Fatty Boom Boom', the author of this article concurs with Sarah Woodward's (2011, 22) interpretation of Die Antwoord's earlier work, in which she contends that 'the myth that Die Antwoord has created in their performance identity has become so integrated into every part of their performance that it loses the knowingness of parody'. The argument made here is that the band's parodic work does not encompass Linda Hutcheon's (1989) understanding of postmodern parody; that is, a double process of inscription and subversion of its subject. The subversion of postmodern parody relies on its ability to inscribe familiar references to other texts and conventions of the genres to which it alludes. These familiar references are inscribed sufficiently to bring the hegemonic meanings and conventions to the surface. Once this happens, these dominant meanings and conventions are subverted in order to level critical commentary at processes that normalise hegemonic conventions and discursive practices. One could make sense of this by considering Dick Hebdige's theorisation of subculture (1979). Hebdige (ibid, 90) contends that the subversion of subcultural style involves 'an actual mechanism of semantic disorder: a kind of blockage in the system or representation'. Subcultures represent noise: 'interference in the orderly sequence which leads from real events and phenomena to their representation in the media' (ibid.). Postmodern parody therefore operates at the level of signification by appropriating hegemonic signifiers and associating them with counterhegemonic signifieds, to create a critical and often playful dialogue with hegemonic signifieds. This is what separates it from mere pastiche, or blank parody. Instead, Die Antwoord's use of blackface and their misogynist representation of Lady Gaga inscribe conservative racial and gender politics, but do every little to subvert such politics. It is in this sense that their work does not constitute the knowingness of parody, unlike Haze's subversion of 'Bitch Bad' by Fiasco. Their work is perhaps better understood via Lisa Colletta's (2009) discussion of postmodern irony and satire in the work of US television comedians Jon Stewart and Stephen Colbert. Colletta argues:

Postmodern irony does not aim to get us to turn off the television, but to entertain us into staying tuned and to be consumers of all cultural products, all the while reassuring us with a wink that we are in on and somehow superior to the giant joke that is being played on us. (ibid, 857)

Die Antwoord's approach is not very different from mass media strategies aimed at keeping audiences tuned in and ensuring that they keep consuming cultural products. Their work operates 
in the mode of Jean Baudrillard's (1994) simulacrum, which revels in the free play of the signifier without resort to a signified and inaugurates 'a liquidation of referentials' (ibid, 2). According to Baudrillard, "simulation threatens the difference between the "true" and the "false", the "real" and the "imaginary" (ibid, 3). It is from this perspective that the band's affinity for mythmaking about and nostalgia for 'zef' (see below), their origins and the band members' identities, make sense. Baudrillard (ibid, 6) writes that when 'the real is no longer what it was, nostalgia assumes its full meaning. There is a plethora of myths of origin and of signs of reality'. In the end, this endless free play glosses over the band's failure to acknowledge the extent to which 'white' privilege shaped their commercial success in a post-apartheid context that has embraced neoliberal economics at the expense of the 'black' majority - an embrace that effectively undermines marginal artists' attempts to represent themselves on their own terms. This article works from the assumption that access to media and participation in the production of media play important roles in facilitating active citizenship in a functional democracy. ${ }^{3}$ If racism still pervades entertainment media, thanks to the persistence of blackface and cultural appropriation, it is questionable whether the benefits of citizenship are extended to all subjects in our democracy.

\section{BLACKFACE, ZEF STYLE...}

Die Antwoord describe themselves as a 'zef' rap rave crew. The origins of the term 'zef' are debatable, and are a part of their mythmaking strategy. They went viral on social media platforms in 2010 and toured extensively in the US, United Kingdom (UK) and Europe. They also signed a record deal with Interscope, owned by Universal, but then left the label at a later stage. Die Antwoord is made up of Ninja (Waddy Jones), Yo-Landi Vi\$\$er (Anri du Toit) and DJ Hi-Tek, who has been played by different people in their videos. Jones' previous rap projects include Original Evergreen, Max Normal, Max Normal.TV and Constructus Corporation. These English rap ventures were not particularly successful. It was not until Jones adopted the Afrikaans working-class persona, Ninja, that he became truly successful. As Sean O' Toole (2012) points out, Jones is neither working class nor Afrikaans-speaking. In fact, an analysis of the lyrics to 'Enter the Ninja' reveals that the song's crossover appeal lies in the fact that it is largely written in English and contains Afrikaans phrases and cuss words (Haupt 2012). For example, consider Ninja's opening verse in 'Enter the Ninja':

I'm a ninja. Yo, my life is like a video game,

I maintain when I'm in the zone. One player, one life on the mic, limited time

Yo ninja, go! No fucking around, I'm cutting down anyone in my path trying to fuck up my game with razor sharp lyrical throw-stars, here my flow's hot

Ho\$tyle [gangster style], wild out of control

Ninja skop befokte rof taal [Ninja kick cool / fucked up crazy rough language], rough rhymes for tough times

Met fokol kos, skraal [With fuck all food, skinny / poor], till I hit triple 7 at the ATM, straight famine or feast when you living on the razor edge, stay sharp sharprolling with the \$o $\$$ high-energy you never seen zef so fre\$h, uh! (Die Antwoord 2009; lyrics from www.watkykjy.co.za) 
The lyrics' syntax is largely in English with Afrikaans words and phrases inserted - for example, the reference to Ninja's use of befokte rof taal. The cultural capital of this rough language comes from allusions to Cape Flats gangs - Ho\$tyle. The appellation 'Ho\$h' (pronounced 'hawss') is often visible on concrete fences and the walls of council flats in Cape Flats townships such as Manenberg, Hanover Park and Elsies River, and operates as an index of Cape 'coloured' gang culture. This allusion to 'coloured' criminality is reinforced by Ninja's narrative about robbing the local ATM, thereby hitting 'triple 7' (winning money on a casino slot machine). Jones therefore borrows heavily from male, 'coloured', Afrikaans-speaking working-class stereotypes, particularly that of the Cape Flats gangster. Ironically, Cape Afrikaans and Xhosa rappers have not achieved local or international success on the same scale as Jones. In fact, Cape Afrikaans rappers such as Prophets of da City and Brasse vannie Kaap did a great deal to pave the way for Afrikaans and African language hip-hop in the 90s and early 2000s (Haupt 2012). Although Die Antwoord make questionable claims about leading the 'zef counter-culture movement', it is interesting that they link the term - which apparently means 'common' or 'kitsch', but also 'cool' - to eighties 'white' working-class culture. Die Antwoord's ambiguous allusion to both working-class 'white' and 'coloured' stereotypes could be read as cultural appropriation, and is an indication that class, not race, accounts for commonalities between 'white' and 'coloured'4 identities. Apartheid's attempts to employ race as a marker of difference are subverted by the dynamics of class and poverty - hence the National Party's post-war project to fast-track 'white' Afrikaners' class ascendance through institutions such as the Broederbond. Elsewhere, the author of this article (Haupt 2012) analyses 'Enter the Ninja' to suggest that the crew's use of Cape dialects of Afrikaans, prison gang tattoos and other stereotypical markers of 'coloured' masculinity, amounts to blackface. Eric Lott $(1993,3)$ reveals that blackface minstrelsy took shape in 19-century America, when 'white men caricatured "blacks" for sport and profit' by painting their own faces black and performing exaggerated, 'white' racist caricatures of 'black' subjects for 'white' audiences. These performances were so popular with 'white' audiences that 'black' artists themselves were not as successful in this respect as their 'white' counterparts, thereby highlighting the idea these were 'white', racist projections of blackness that had little to do with the lived experiences of 'black' subjects during and after the era of slavery in the US. Jonathan Hart (1997) frames this racist tradition in terms of the unequal relations of power between slave owners and slaves, as well as between 'white' landowners/employers and their 'black' employees: 'The debate over cultural appropriation is about whether speaking for others or representing them in fictional as well as legal, social, artistic, and political work is appropriate or proper, especially when individuals or groups with more social, economic, and political power perform this role for others without invitation' (ibid, 137). Die Antwoord's most recent music video, 'Fatty Boom Boom', literally embodies this racist theatre and cinematic tradition when Yolandi's body is painted black. As Claire Scott's (2012, 758) analysis of their performance of 'white' identity suggests, 'while their performance places South African whiteness under the spotlight, it also obscures the inherited privileges that 'white' South Africans retain and claim unquestioningly'. In his discussion of music history and cultural appropriation, Perry Hall $(1997,34)$ holds that 'white' artists and fans' fascination with 'black' 
cultural expression has been 'obscured or distorted by racist habits of thoughts and association that provoke suppression and denial'. In essence, Die Antwoord's ability to convert the stereotypes and cultural expressions of 'coloured' and 'white', Afrikaans and 'coloured' communities into symbolic capital underscores their own position of 'white' class privilege in post-apartheid South Africa - something that they do not explicitly acknowledge in their appropriation of these marginal communities' shared experiences and expressions. In the video we see Yolandi's entire body painted black; her yellow baby-doll dress, yellow eyes and bleached hair accentuate her black body paint. These shots alternate with images of Ninja, Yolandi and their dancers in white body paint and then later in black. How do we read Yolandi's blackened body? How do we read the band's invocation of a racist tradition of theatre, music and cinema in the US and South Africa's history of the coon carnival? (Erlmann 1996; Maingard 1997). Are they deconstructing our racist past, or is it a publicity stunt - a shot at another viral YouTube video? A clue to these questions may be found in a remark Jones made during an interview: 'God made a mistake with me. I'm actually black, trapped in a white body' (Van Wyk 2012). This statement is echoed in lyrics from the song 'Never le Nkemise' (off Ten\$ion): 'Ninja, die wit kaffir / Ja, julle naaiers / Skrik wakker' [Ninja, the white kaffir / Yes, you fuckers / Wake up] (Die Antwoord 2012). Yolandi and Ninja 'go native' by blackening up for profit and sport. They have the means to convert marginal subjects' cultural expressions into symbolic capital. If these remarks are meant to be parodic, it is not clear what dominant meanings in the references to the history of blackface are meant to be subverted. ${ }^{5}$

'Fatty Boom Boom' differs from their earlier work, because the band's blackface politics goes beyond the conversion of marginal subjects' cultural expression into symbolic capital via their appropriation of language, music genres and stereotypes. In this video, Yolandi is literally painted black, thereby directly referencing the history of blackface minstrelsy without offering any indication of the ways in which this history is being critiqued or subverted. This lends credence to the idea that these sorts of reference merely amount to pastiche, and do not constitute postmodern parody, as Hutcheon (1989) defines the term. It is unknowing or blank parody. Yolandi's lyrics also offer few clues about the subversive potential for literal references to blackface in the video:

Hi my name is...

Yo-landi fokken Vi\$\$er! Fight fight fight!

Kick $u$ in da teef! Hit $u$ on da head wif da mic!

Dere's a rumble in da jungle I'm bubbling 2 da beat

I'm not looking 4 trouble but troublez looking $4 \mathrm{me}$

My pockets $r$ fokken swollen but nuffing jus cum 4 free

I used 2 beg borrow or steal jus 2 hustle sumfing 2 eat

Souf Afrika used 2 b 2 dwankie 2 notice me

Suddenly u interested cause we blowing up overseaz

Making money money money! Yes yes yes!

Zefside represent! U fucking wif da best

I'm a upper! Dwankiez get popped like a sucker

Baka baka! Yipee kaiyay muddafucka! 
I'm a big deal! Yo krazy money get thrown at me

Now I'm having so much dat I can't even go 2 sleep!

Yo-landi! Wat? Where u at? Here I am!

Spitting fokken lyrix like bam bam bam! (Die Antwoord 2012; transcription obtained from http://www. azlyrics.com/lyrics/dieantwoord/fattyboomboom.html)

The song is largely in English, albeit a non-standard dialect of English that comes across as somewhat infantilised - an approach that matches the childish 'fatty boom boom' taunt directed at Lady Gaga in the chorus. The song is therefore accessible to international English-speaking audiences. The invocation of violent rhetoric aside, Yolandi's lyrics employ a 'rags-to-riches' cliché to describe her rise from obscurity to international fame, complete with the familiar gangsta rap narrative of hustling the streets for money - a narrative which embraces neoliberal economics and valorises the individual accumulation of capital at the expense of collective wealth and welfare (Haupt 2008). This is reminiscent of Richard Schur's (2009) comparison between gangsta rappers' 'bling' politics and slaves during the era of slavery. Schur asserts that both slaves and hip-hop artists are/were excluded from the market economy. It is for this reason that hip-hop's aesthetics 'reenacts the slave narratives' desire to become the subjects of property law'- if they were the objects of property law, they could not possibly be full subjects (ibid, 8). In a music market dominated by four holding companies with approximately 75 per cent of global market share (Patry 2009) and in a historical context where the cultural appropriation and commercial exploitation of 'black' music was commonplace, it is ironic that Die Antwoord would employ hip-hop narratives about hustling, the struggle for acceptance in the music industry, and the obsession with money. This is especially ironic because Jones is neither 'white' Afrikaans nor 'coloured' Afrikaans working class, but comes from a privileged, English background (O'Toole 2012) - he has the sufficient social (and economic) capital to convert marginal subjects' cultural expressions into commercially successful projects. Analysing the operation of blackface in gangsta rap, Michelle Alexander $(2010,168)$ contends that 'today's displays are generally designed for white audiences' - this may explain Die Antwoord's references to gangsta rap. Significantly, it is hard not to read their work in relation to K.J. Greene's (1999) research on cultural appropriation: 'A strikingly consistent characteristic of cultural appropriation is its one-way direction - white performers obtaining economic and artistic benefits at the expense of minority innovators' (ibid, 368). Greene elaborates that the

distortion and devaluation of Black art in the past was illustrated by the minstrel shows, which appropriated Black music and dance for the service of social stereotyping. Similarly, because Black artists were not considered acceptable to mainstream (white) audiences, 'covers' of black recordings by white artists become commonplace in the recording industry. (ibid, 369)

In other words, relations of power played out along racial lines in the entertainment industry, allowing 'white' artists to achieve commercial success at the expense of 'black' artists. No doubt Die Antwoord's lyrical performance is a key part of the band's overall presentation of its members 'in character' and attempts to defy any recourse to the signified, instead revelling in endless signification in order to frustrate attempts to pin them down - simulation, in other words. However, 
the signifiers they employ are marked by a very specific kind of racial and gender politics that references our racist and sexist past and present.

The video apparently pokes fun at stereotypical Western perceptions of Africa. Hence, it features a male Lady Gaga impersonator - wearing Gaga's now-infamous meat dress - in a ramshackle minibus taxi as she is taken on a tour of what is presumably inner-city Johannesburg. Her tour guide/taxi driver points out wild animals in Rockey Street before the vehicle is hijacked. Gaga escapes from the scene and enters the surgery of a dentist/gynaecologist - here she gives birth to a large cockroach, which South Africans (specifically residents of Johannesburg) would probably link connotatively to its nickname, Parktown Prawn. This is also a reference to the alien 'prawns' in the South African sci-fi movie, District 9, which was nominated for four Academy Awards: Best Picture, Best Adapted Screenplay, Best Visual Effects and Best Editing. Later, a lion kills Lady Gaga, still in her meat dress. Die Antwoord's attempts at parody and contempt for Gaga, who wanted them as an opening act on her tour in 2012, can hardly be missed. She is the 'fatty' who is mocked in the chorus; Gaga reportedly picked up weight at the time of this video's release. Talia Meer (2013) contends that 'amid tabloid skinner about Lady Gaga's weight and her disclosure of her struggles with anorexia', 'this video reaffirms that the best way to bring a girl down to size is to pick on her size'. Meer argues that in the scene with the African gynaecologist 'the depiction of vaginal mucous and the removal of an insect from the vagina are loaded in a global culture that vilifies women's bodies and sexuality and portrays vaginas as requiring douching, perfuming and bejewelling' (ibid.). Meer links the stigmatisation of the female body to the prevalence of genderbased violence in South Africa, by asserting that 'this music video is yet another depiction of women's bodies as sexualised, violated and diseased' (ibid.). These remarks are in line with Anne Burrows and Sally Johnson's (2006) research on girls' views of menarche and menstruation. Their respondents' views 'seemed to reflect dominant representations of menarche and menstruation identified by feminists: something to be ashamed of, embarrassed about, kept secre[t] and an illness' (Burrows and Johnson 2006, 246). They conclude that 'resistance and more positive representations will not come easily in the face of hegemonic cultural scripts of menstruation and socialization practices which prepare girls to behave in powerless ways' (ibid, 247). By the time the lion has attacked Gaga, the punchline is that she asked for it: 'the mini-meat dress and the lion, and the miniskirt and the sexual predator, invoke the already pervasive view: it is her fault' (Meer 2013). The message is that the lion would not have attacked her if she were not wearing a meat dress. The punchline resonates with conservative explanations for women's experiences of violence: that the victim of gender-based violence is somehow to blame for the act of violence through her behaviour or attire (Boonzaier 2008; Stevenson 2000). Therefore, Die Antwoord do not engage in a double-process of inscription and subversion; they merely inscribe conservative gender politics onto the female body, which becomes the terrain upon which the band fights its ego battle with the pop star, thereby enacting and legitimating yet another media representation of femicide. It is in this sense that their work does not constitute knowing parody, but merely invites endless signification that feeds the tabloid frenzy and encourages audiences to stay tuned as consumers. In essence, the potential for social media platforms (such as YouTube, where the video 
was released) to act as spaces for subjects to be producers, and not just consumers, is reduced to the tendency of the commercial mass media to interpellate subjects merely as loyal consumers, and, thereby, 'purchase' consent for hegemonic representations of women.

\section{CONTESTING BLACKFACE IN POP CULTURE}

These types of representational politics do not go unchallenged, however. US rapper Lupé Fiasco's 'Bitch Bad' pays tribute to African American actor Paul Robeson, by demonstrating the extent to which blackface minstrelsy has continued to operate in contemporary popular culture well after Robeson's death in 1976. The song seems to reference gangsta rapper 50Cent and the video vixens (the derogatory term is 'video hos') who feature in gangsta rap music videos. The video vixens' pink and green wigs in this video are reminiscent of those worn by Nicki Minaj. The opening shot of the video is presented in sepia. The old-fashioned signposting above the entrance to a theatre displays an advertisement for a show: 'Sugarwater presents Lupé Fiasco Bitch Bad'. The colour grading of the shot and the architecture allude to the 1950s and early 1960s in theatre and cinema. This impression is confirmed in the next shot, which is a wide angle of the Tower Theatre, revealing a box office with double doors on either side. To the right, a 'white' man in a black suit and black hat is counting money as he leans against a wall close to where a 'black' man in overalls is placing a Fiasco poster in a display case. The retro architecture, colour grading and wardrobe of the two characters in this scene locate the narrative in the early history of modern cinema and popular culture. The implied narrative is that the 'white' theatre owner is making a considerable amount of money from the show being advertised. The third shot reveals the two characters in a low-angle mid-shot. A clearly satisfied theatre owner is shown holding stacks of dollar bills as he clenches a cigar between his teeth. The next shot formation takes us into the theatre: Fiasco sings into an antique microphone as a male and female performer don their make-up and costumes in their dressing-rooms, and the gleeful theatre owner's open hand is seen stretched out from the box office, presumably towards a customer. Immediately preceding this shot, there is a closeup of the owner's smiling face. This sequence does not merely contain shots of the performers getting dressed - for example, the 'black' male actor is clearly getting into character as a gangster, complete with bandana and silver teeth, while the 'black' female actor is about to put 'chicken cutlets' in her bra, presumably to make her breasts look bigger. What is most striking is a shot of someone burning cork in a silver dish. This, the first sign of Fiasco's critique of gangster rap, is a reference to the practice of blackface minstrelsy mentioned earlier: the cork is burned and then mixed with petroleum jelly to produce a black paste which is subsequently smeared onto blackface performers' faces. The dressing-room scene resembles those in Spike Lee's Bamboozled (2000), which tells the story of a Harvard-educated 'black' studio producer, Delacroix (Damon Wayans), who is under pressure from his somewhat obnoxious 'white' boss, Dunwitty (Michael Rappaport), to produce a hit television show. One of the reasons why Delacroix is annoyed with Dunwitty, is that he believes he is entitled to make remarks about 'black' communities and can lay claim to aspects of 'black' cultural practice because he is married to a 'black' woman. In one scene, he tells Delacroix: 'Brother man, I'm Blacker than you. I'm keeping it real ... ' (Lee 2000). Delacroix 
devises a treatment for a show that is so racially offensive that he is bound to be fired. However, Dunwitty loves the proposed New Millennium Minstrel Show and they start shooting the television programme. The actors are literally required to blacken up and perform racist stereotypes in the minstrelsy tradition. The first dressing-room scene is tense as both actors go through the racially loaded process of blackening up, by starting to burn cork in a dish. Like Lee's film, Fiasco intends to critique the legacy of minstrelsy in the US entertainment industry, and, as in Bamboozled's montage of Hollywood films, projections of old Hollywood films featuring actors in blackface are later shown in the background, as Fiasco raps in the foreground. Toward the end of the song, as it reaches a climax, both actors are seen applying burnt cork to their faces; they perform before their dressing-room mirrors as minstrels and begin to break down emotionally. In one scene, the female performer injects her buttocks with what is possibly Botox - in all likelihood, a reference to the ways in which video vixens and female pop performers are meant to live up to sexist and racist body aesthetics. Patricia Hill Collins (2005) and T. Denean Sharpley-Whiting (2007) write about the appeal of Latina or fair 'black' models in these music videos. Hill Collins (2005) contends that the fascination with racially ambiguous females with fair skins, long straight or curly hair, as well as large buttocks or thighs, has taken on the same kind of racist and sexist dimension as Europe's fascination with Sarah Baartman. In her discussion of hypersexualised representations of 'black' female pop icons, Hill Collins (ibid, 27) contends that 'the distinctive sexualized spectacles performed by Baartman, Baker, Destiny's Child, and Lopez invoke sexual meanings that give shape to racism, sexism, class exploitation, and heterosexism'. She adds that each 'spectacle marks the contradictions of Western perceptions of African bodies and of Black women's agency concerning the use of their bodies' (ibid, 27-28). Sharpley-Whiting $(2007,27)$ offers a similar interpretation, stating that 'the vast majority of the young women in these videos are either fairer-skinned, ethnically mixed, or of indeterminate ethnic/racial origins, with long, straight, or curly hair [which] would suggest that along with the stereotype of hypersexuality and sexual accessibility, a particular type of beauty is offered up as an ideal'. The Botox scene makes sense from this perspective - as does the fact that the female performer is fair-skinned, slender and that the editing and her dance moves draw attention to her buttocks and thighs. Like Delacroix, who dies at the end of the film, partly by his own hand, both video performers break down under the pressure of the stereotypes they perform. Even though they are not seen performing on stage in blackface, the viewer is meant to think of their gangster rap music video performances as a metaphorical form of blackface.

\section{THE KNOWINGNESS OF PARODY: HIP-HOP'S CRITICAL DIALOGUE}

In his rhymes, Fiasco sets up a scenario in which a boy drives with his mother as she sings along to a song on the radio: 'Niggas, I'm a bad bitch, and I'm bad bitch far above average' (Fiasco 2012). Hill Collins $(2005,126)$ writes that one 'sign of a ["black"] "Bitch's" power is her manipulation of her own sexuality for her own gain'. She contends that this 'theme of ... materialistic, sexualized Black women has become an icon within hip-hop culture' (ibid, 126). However, the 'difficulty lies in telling the difference between representations of Black women who are sexually liberated and 
those who are sexual objects, their bodies on sale for male enjoyment' (ibid.). As Fiasco raps, the scene unfolds on stage in what is presumably the inside of the Tower Theatre. Fiasco questions what effect this scene will have on the young, impressionable boy's mind. In another scenario, he raps about young girls surfing the Internet without parental supervision, which he believes is a moot point, given that they are probably more tech-savvy than their parents. The girls come across a gangster rap video, and the 'black' male and female performers, who featured in the opening dressing-room scenes, appear on stage behind the girls as they are entertained by the images on the laptop on the ground before them. The actors portray familiar gangsta rap video scenes: the male is the thugged-out rapper with the modified car, gun and jewellery, while the female is the video vixen in a gold g-string bikini, black push-up bra and wig. As the video's 'eye candy', she is positioned as one of the props that signify the gangster rapper's power and wealth - she is 'acquiescent to his whims' (Fiasco 2012). Again, Fiasco offers an evaluation of what young minds would make of these performances - specifically that of the woman in the video: 'They don't see a paid actress, just what makes a bad bitch' (Fiasco 2012). In the final scenario that he sets up, the little boy meets one of the girls who were entertained by the video:

The little boy meets one of those little girls

And he thinks she a bad bitch and she thinks she a bad bitch

He thinks disrespectfully, she thinks of that sexually

She got the wrong idea, he don't wanna fuck her

He thinks she's bad at being a bitch like his mother

Momma never dress like that, come out the house, hot mess like that

Ass, titties, dress like that

All out to impress like that

Just like that, you see the fruit of the confusion

He caught in a reality, she caught in an illusion

Bad mean good to her, she really nice and smart

But bad mean bad to him, bitch don't play your part

But bitch still bad to her if you say it the wrong way

But she think she a bitch, what a double entendre. (Fiasco 2012)

The boy's understanding of the term 'bitch' therefore differs markedly from that of the girl and they seem to talk at cross purposes. In the words of Hill Collins, is she sexually liberated, or is she a sexual object on sale for male enjoyment? One might say that both characters are caught in Baudrillard's simulacrum, given that so much of their understanding of gendered identities and sexuality is mediated by entertainment media, to such an extent that there is no recourse to the 'real'. Even though Fiasco attempts to draw a distinction between what is real and what is illusion, the gender politics are somewhat murky. This is evident in the chorus, when he raps: 'Bitch bad, woman good / Lady better, they misunderstood' (Fiasco 2012). Blogger Megan Murphy (2012) contends that despite his attempt to engage critically with mainstream hip-hop's gender politics, Fiasco "succeeded mostly in reinforcing dichotomies about "good" women vs. "bad" women ("ladies" vs. "bitches") and then blamed women rather than men for perpetuating a misogynistic 
culture, failing to hold men accountable for how they treat women'. The blame for the confusion in the boy's mind is also laid with the mother, who sings along to the song in the car (ibid.). Likewise, the action of the girls viewing videos on the Internet is not linked to the agency of the men in the issue under discussion, nor is the blame directed at men and broader patriarchal systems (ibid.). Murphy (2012) points to Angel Haze's rebuttal to 'Bitch Bad', which revisits the scenarios presented to Fiasco in an attempt to point to male complicity in sexism and misogyny. The opening scenario is that of a single mother who struggles to make ends meet, before she eventually meets a man:

His mother meets a man with ample amount of funds

But in order to get that, she's gotta give 'em some

So he treats her like a, beats her like a, cleans her up and keeps her like a

Screams and yells and treats her like a

Like a bitch, well

You wonder how she got the whole idea

Her ear to the wall, she could hear him pretty clear yelling

Ooh, you make me mad, bitch, shut up or get slapped, bitch

Roll over you stand, bitch, who's the fucking man, bitch?

See what I'm saying is the bed you make you lay in

But what you put out well it kinda remains the same, uh?

Well you might not be believing what you hear

But the objects they tend to mirror be closer than they appear so

To sit instead she learned it from her mother

But imagine how it all affected her little brother. (Angel Haze 2012)

Angel Haze places the blame for the abusive behaviour that the boy will internalise and later act out at the door of abusive men, as well as the dire poverty that made limited options available to his mother. But even here, she does not deny her characters agency. They are not doomed to act out a predestined script with some opportunity for introspection, as is the case in Fiasco's song. The boy becomes a father to a daughter and also gains insight:

Now as they grew up in the world

The little boy's lost and has him a little girl

And his life changes, it's hers again, he don't ever wanna see hurt by men

To protect her from everything on earth if he can

And that moment he understand

Woman should never be hurt by words or hands

And just like that that little boy becomes a man. (Angel Haze 2012)

Although the boy has internalised a set of negative ideas about women and has learned to act out abusive and misogynist behaviour, he is able to break the cycle of abuse through the unconditional love and protectiveness he feels for his own daughter. In many respects, the song is a perfect example 
of the knowingness of parody. Haze employs the same kind of narrative and rhyme structures as those used in Fiasco's song. She employs the same chorus (or 'hook', in hip-hop discourse), song title and musical arrangement (based on similar loops and samples). The song is thus recognisable to Fiasco fans: the original song and its associated meanings are inscribed, only to be subverted by the realisation that this offers a rebuttal to Fiasco's lyrics. In fact, without paying close attention, it would be possible to assume that Haze was performing a cover of Fiasco's 'Bitch Bad'. Although Fiasco aims to issue a challenge to continuing racism and sexism in the music industry, he confirms hegemonic understandings of gender identity and role-modelling. Haze's parody of 'Bitch Bad' points to male complicity and class inequalities as key causes of the problems Fiasco attempts to address in his music video. In essence, her parody is an example of hip-hop's potential to deconstruct hegemony and facilitate dialogue about key social issues. This approach contrasts markedly with Die Antwoord's intertextuality, which merely references enduring colonial views of Africa and mocks 'fatty' Lady Gaga, thus inscribing conservative gender politics. In order for their act to work, Die Antwoord need to appropriate aspects of Afrikaans working-class 'white' and 'coloured' stereotypes and cultural practices, without actually facilitating dialogue about the issues that affect these communities; without acknowledging that they do not share the lived experiences of these marginal communities. Whereas Die Antwoord appropriate, Angel Haze reveals that postmodern parody's double process of inscription and subversion still has the potential to produce creative, playful and politically meaningful insights into a monopolistic music industry context which seems overdetermined by commercial imperatives.

Die Antwoord's conservative race and gender politics should be read in relation to broader concerns about the role of the media in a relatively functional democracy. Arguments about cultural appropriation, continuing 'white' minority privilege and the persistence of misogyny in the entertainment media, raise questions about whether enough is being done to offer more diverse access to media and cultural platforms, be they mass or social media production tools. The answer does not necessarily lie in censoring cultural production or the media as a whole, but in reworking the structural mechanisms (such as economic policy) that prevent wider access to the tools of production and distribution. Wider access would ensure that our democracy is enriched by diverse political and cultural expressions which promote robust debates and challenges. Die Antwoord's local and international success underscores the fact that South Africa's class divisions are still racialised, and that privileged artists are able to go 'viral' and overcome the limitations of Africa's digital divide by virtue of the social and economic capital they continue to access to the exclusion of more marginal artist such as Hemel Besem, Jitsvinger, Burni Aman or Soundz of the South, for example. In the end, the sensational challenge to Lady Gaga - who is signed to their former music label, Interscope - is anything but a local David versus the global, monopolistic Goliath. Instead, it is evidence of seemingly endless misogynist and racist signification. 


\section{CITIZENSHIP WITHOUT REPRESENTATION?}

Some of the questions that emerge from this article include: What is citizenship without representation? Is it not meaningless, especially in the field of youth cultural production, given that youth culture is so heavily exploited by corporate media? Die Antwoord's success in social media and their ability to tour extensively in the global north show that the power of the social media actually reinforces inequities which post-apartheid South Africa inherited from apartheid. The extent of marginal subjects' participation in media production, as an indicator of their ability to express themselves freely, is linked to their status as citizens in a functional democracy. Marginal subjects' inability to represent themselves on their own terms, as underscored by Die Antwoord's commercially successful cultural appropriation and gender politics, show up the point at which arguments about agency in the era of social media break down. The critiques by Fiasco and Angel Haze drive the point home: an effective challenge to the cultural politics demonstrated by Die Antwoord can only be produced from the centre, if it is to access wider audiences - that is, from within the so-called Empire (but, even then, this is no guarantee of success). Michael Hardt and Antonio Negri (2000) use the term 'Empire' to signify the rise of corporate globalisation and multilateral organisations such as the World Trade Organisation, the International Monetary Fund and the United Nations, after the Second World War. Hardt and Negri (ibid.) contend that former colonial powers have shifted away from competing with each other for resources in the former colonies, toward multilateral cooperation with each other to ensure that they can exploit the resources of former colonies without necessarily having to occupy them militarily. This means they have effectively lowered the operational costs of running and policing these colonies, while continuing to reap financial benefits from ongoing economic relations between Western investors and the new elites who now run these new independent, post-colonial states (Collins 2005; Hardt and Negri 2000). The colonies' transition to independence was thus conditional upon retaining the economic privileges that the colonial powers secured during their rule. South Africa is no exception in this regard. As Michael MacDonald (2006) argues, South Africa's transition to democracy was also conditional upon ensuring the continuation of 'white' privilege:

The transition from apartheid to democracy occurred through a deal. In its broadest sweep, whites traded the racial state, which expressed and favored their identity and interests, for assurances about civil liberties, property, and economic policy. The disenfranchised majority received democratic political institutions, empowering them to elect black leaders, but on condition that property rights were respected and orthodox economic policies were adopted. (ibid, 178)

The orthodox economic policies that MacDonald mentions are essentially neoliberal, ensuring tariff liberalisation, inflation targeting and low fiscal deficits (Mohamed 2010, 158). Seeraj Mohamed $(2010,158)$ contends that the state plays a smaller role in the economy, and that this approach 'meant that inadequate attention has been paid to the structural weaknesses of the economy'. South Africa has failed to diversify manufacturing away from mining and this has led to a decline in manufacturing, generally speaking (Mohamed 2010). Mohamed (ibid, 159) counters arguments that South Africa is moving from a manufacturing to a service economy, with the assertion that 
the country is a 'destination for short-term portfolio investment flows and not long-term direct investment flows'. The country is thus vulnerable to capital flight, thereby undermining arguments about the ability of foreign direct investment to create meaningful employment for its citizens. In this regard, Hardt and Negri (2000, xii) argue that the 'declining sovereignty of nation-states and their increasing inability to regulate economic and cultural exchanges is in fact one of the primary symptoms of the coming of Empire'. It is from this perspective that sense can be made of the US entertainment industry's ability to access global markets, with little opportunity for reciprocity.

\section{CONCLUSION}

One lesson to be learnt from this, is that participation in public discourse on the scale of that produced by Die Antwoord, Lady Gaga, Lupé Fiasco or Angel Haze, is conditional upon the extent to which the artists are able to access varying privileges of class, race, gender, global corporate media and technology, in order to produce their conservative or radical performances. This underscores Hardt and Negri's (2000, xii) claim that Empire undermines the nation-state's ability to 'regulate cultural and cultural exchanges'; citizenship becomes meaningless in the face of global capital's deterritorialising power. Subjectivity is reterritorialised, reconstituted by global capital which is not accountable to democratic polities. Die Antwoord's success demonstrates that it is 'white' privilege that allows them to overcome the limitations of the digital divide, to access global markets with their repackaging of suspect gender and racial politics. The inability of 'black' subjects to participate in representational politics on their own terms, as demonstrated by Fiasco's critique of blackface in his video, is therefore more than just about 'black' subjects' difficulty to access or produce media on a global scale on their own terms. It also reveals the disconnect between subject and state, or subject and citizen, thus lending credence to Hardt and Negri's (ibid.) argument about the 'declining sovereignty of nation-states'. As the history of cultural appropriation in the entertainment media and legislated discrimination under apartheid suggest, this disconnect is not new at all. Historically, the state failed those 'black' subjects who were not afforded the rights of citizenship during the colonial era, and this failure has continued in the age of Empire with its focus on soft power, as opposed to coercion. In the end, the global appeal of Die Antwoord or Lady Gaga tells us about the extent to which diverse cultural expressions are sidelined by the reach of the global media: only certain kinds of public discourse become hegemonic, and therefore the ability of marginal subjects to contest the ways in which they are represented, is limited. Effectively, this globalised and somewhat diluted and distorted packaging of racialised, gendered and class identities frustrates, for example, the efforts of Afrikaans, 'coloured' working-class subjects to exercise citizenship through modes of speech and performances on their own terms. The identities and modes of articulation are always-already mediated by colonial notions of 'blackness' and 'colouredness', which are amplified by global corporate media that are largely owned by the global north [read: Empire]. Considerations of the value of political representation through the electoral system aside, representation in mass media and newer forms of media continue to reflect some continuity between the apartheid and post-apartheid eras. 


\section{ACKNOWLEDGEMENTS}

Thanks to Oliver Laughland of The Guardian UK for the invitation to write a response to 'Fatty Boom Boom' in October 2012. This article draws on certain aspects of that brief op ed, as well on research for the book Static: Race and representation in post-apartheid South African music, media and film (HSRC Press, 2012), which did not analyse 'Fatty Boom Boom' or either version of 'Bitch Bad'.

\section{ENDNOTES}

1 See Poplak, R. 'Cape Flats calling.' The Walrus Blog, 11 February 2010. Reader comment by Rustum Kozain. http://www.walrusmagazine.com/blogs/2010/02/11/cape-flats-calling/ (accessed February 28, 2010).

2 In his discussion of African Americans' contribution to US popular music, Rebee Garofalo (1994) contends that black artists have a made a considerable contribution to American popular culture. Their cultural expression was readily commodified, despite the fact that they have been systematically marginalised (ibid.). In essence, institutionalised racism ensures that black expression can be commercially exploited without any prospect of equitable reciprocity.

3 The theme of citizenship and media has been the focus of a number of scholars, including Dahlgren (2009), Benkler (2006) and Wasserman (2011).

4 All references to race appear in inverted commas, to draw attention to the contention that race, including 'whiteness', is socially constructed. For an elucidation on race as social construction, see Erasmus (2001).

5 Blackface is not merely limited to contemporary musical performances. The Advertising Standards Authority of South Africa (ASA) recently ordered the withdrawal of a Cape Town Fish Market television commercial which featured a white actor in blackface as an African dictator (Anon 2013). The advert can be viewed on YouTube at http:/www.youtube.com/watch?v=9HOjOLlvBqw

\section{REFERENCES}

Alexander, M. 2010. The new Jim Crow: Mass incarceration in the age of colorblindness. London and New York: The New Press.

Anon. 2013. Fish ad gets canned for being racist. Channel 24. http://www.channel24.co.za/TV/News/ Fish-ad-gets-canned-for-being-racist-20130904 (accessed September 7, 2013).

Baudrillard, J. 1994. Simulacra and simulation. Trans F. Faria Glaser. Ann Arbor: Michigan University Press.

Benkler, Y. 2006. The wealth of networks: How social production transforms markets and freedom. New Haven \& London: Yale University Press.

Boonzaier, F. 2008. 'If the man says you must sit, then you must sit': The relational construction of woman abuse - gender, subjectivity and violence. Feminism \& Psychology 18: 183-206.

Burrows, A. and S. Johnson. 2005. Girls' experiences of menarche and menstruation. Journal of Reproductive and Infant Psychology 23(3): 235-249.

Colletta, L. 2009. Political satire and postmodern irony in the age of Stephen Colbert and Jon Stewart. The Journal of Popular Culture 42(5): 856-874. 
Dahlgren, P. 2009. Media and political engagement: Citizenship, communication and democracy. Cambridge, New York and Cape Town: Cambridge University Press.

Die Antwoord. 2012. 'Never le Nkemise.' Ten\$ion. Zef Records, Universal Music Group.

Erasmus, Z., ed. 2001. Introduction: Re-imagining coloured identities in post-apartheid South Africa. In Coloured by history, shaped by place. Cape Town: Kwela Books and SA History Online.

Garofalo, R. 1994. Culture versus commerce: The marketing of black popular music. Public Culture 7: 275-287.

Greene, K.J. 1999. Copyright, culture, and black music: A legacy of unequal protection. Hastings Communication and Entertainment Law Journal 21: 339-392.

Hardt, M. and A. Negri. 2000. Empire. London and Cambridge, MA: Harvard University Press.

Haupt, A. 2008. Stealing Empire: P2P, intellectual property and hip-hop subversion. Cape Town: HSRC Press.

Haupt, A. 2012. Static: Race and representation in post-apartheid music, media and film. Cape Town: HSRC Press.

Hebdige, D. 1979. Subculture: The meaning of style. London and New York: Routledge.

Hill Collins, P. 2005. Black sexual politics: African Americans, gender and the new racism. New York and London: Routledge.

Hutcheon, L. 1989. The politics of postmodernism. London and New York: Routledge.

Lott, E. 1993. Love and theft: Blackface minstrelsy and the American working class. New York and Oxford: Oxford University Press.

MacDonald, M. 2006. Why race matters in South Africa. Scottsville: University of KwaZulu-Natal Press.

Maingard, J. 1997. Imag(in)ing the South African nation: Representations of identity in the Rugby World Cup 1995. Theatre Journal 49(1): 15-28.

Meer, T. 2013. Die Antwoord-Are we missing the misogyny? ThoughtLeader. http://www.thoughtleader. co.za/taliameer/2013/01/02/die-antwoord-are-we-missing-the-misogyny/ (accessed February 20, 2013).

Mohamed, S. 2010. The effect of a mainstream approach to economic and corporate governance on development in South Africa. In Constructing a democratic developmental state in South Africa: Potentials and challenges, ed. A. Edigheji, 149-168. Cape Town: HSRC Press.

Murphy, M. 2012. Angel Haze hits Lupe Fiasco's misses with 'Bitch Bad'. Feminist Current. http:// feministcurrent.com/6641/angel-haze-hits-lupe-fiascos-misses-with-bitch-bad/ (accessed May 31, 2013).

O'Toole, S. 2012. Die Antwoord's state of exception. Safundi: The Journal of South African and American Studies 13(3-4): 393-399.

Saxton, A. 1996. Blackface minstrelsy. In Inside the minstrel mask: Readings in nineteenth-century minstrelsy, ed. A. Bean, J.V. Hatch and B. McNamara, 67-85. Middletown: Wesleyan University Press, Hanover, NH.

Sharpley-Whiting, T.D. 2007. Pimps up, ho's down: Hip-hop's hold on young black women. New York and London: New York University Press.

Schur, R. 2009. Parodies of ownership: Hip-hop aesthetics and intellectual property law. Ann Arbor: University of Michigan Press and University of Michigan Library.

Scott, C. 2012. Die Antwoord and a delegitimised South African whiteness: A potential counternarrative? Critical Arts: South-North Cultural and Media Studies 26(5): 745-761.

Van Wyk, P. 2012. Die Antwoord's Ninja: I'm actually black. Channel 24. 
http://www.channel24.co.za/Music/News/Die-Antwoords-Ninja-Im-actually-black-20120217 (accessed February 20, 2013).

Wasserman, H., ed. 2011. Popular media, democracy and development in Africa. Oxon \& New York: Routledge.

Woodward, S. 2011. Ownership and power: Debate and discourse around the subcultural phenomenon Die Antwoord. In African Theatre 10: Media and Performance, ed. J. Gibbs, F. Osofisan and M. Banham. London: James Currey.

\section{YouTube videos}

Angel Haze. 2012. Bitch Bad., https://www.youtube.com/watch?v=uLTcKhyccRc (accessed May 31, 2013).

Die Antwoord. Enter the Ninja. http:/www.youtube.com/watch? $\mathrm{v}=8 \mathrm{NZBxwjcwMc}$ (accessed February 21, 2012).

Die Antwoord. 2012. Fatty Boom Boom. http://www.youtube.com/watch?feature=player embedded\&v=AIXUgtNC4Kc (accessed May 31, 2013).

Lupé Fiasco. 2012. Bitch Bad. https://www.youtube.com/watch?v=C3m3t_PxiUI (accessed May 31, 2013). 